\title{
Top Management Team Stability and Corporate Social Responsibility: The Moderating Effects of Performance Aspiration Gap and Organisational Slack
}

\author{
Qiang Zheng and Danming Lin *
}

Citation: Zheng, Q.; Lin, D. Top Management Team Stability and Corporate Social Responsibility: The Moderating Effects of Performance Aspiration Gap and Organisational Slack. Sustainability 2021, 13, 13972. https://doi.org/10.3390/su132413972

Academic Editors: Thomas J. Walker and Jane McGaughey

Received: 21 October 2021

Accepted: 15 December 2021

Published: 17 December 2021

Publisher's Note: MDPI stays neutral with regard to jurisdictional claims in published maps and institutional affiliations.

Copyright: (C) 2021 by the authors. Licensee MDPI, Basel, Switzerland. This article is an open access article distributed under the terms and conditions of the Creative Commons Attribution (CC BY) license (https:/ / creativecommons.org/licenses/by/ $4.0 /)$.
Business School, Shantou University, Shantou 515063, China; qzheng@stu.edu.cn

* Correspondence: dmlin@stu.edu.cn

\begin{abstract}
Although studies on the impact of senior executives on corporate social responsibility (CSR) are relatively sufficient, they take a static perspective when investigating the different attitudes of senior executives towards fulfilling social responsibility. Few studies consider the impact of the dynamic changes in a top management team (TMT) on sustainable corporate development, especially social responsibility. We perform regression analysis on 2010-2019 data from Chinese listed firms to examine the relationship between TMT stability and CSR performance and consider the moderating roles of the performance aspiration gap and slack resources. We find that TMT stability has a positive impact on CSR performance and that the performance aspiration gap and slack resources negatively moderate the relationship between TMT stability and CSR performance. This study expands the current literature on the relationship between TMT characteristics and social responsibility, sheds light on what situations can cause agency problems, and provides practical guidance for the sustainable development of a firm and adequate performance of CSR.
\end{abstract}

Keywords: top management team stability; corporate social responsibility; performance aspiration gap; slack resources; Chinese listed firm

\section{Introduction}

To foster harmony between humans and nature, firms are guided by the concept of sustainable development, which aims to reduce carbon emissions and promote symbiosis. In recent years, Chinese firms have paid more attention to corporate social responsibility (CSR). This is due to the requirement of the China Securities Regulatory Commission that firms disclose social responsibility reports to display their participation in energy conservation and environmental optimisation. Another important reason is that social responsibility, as a part of the image representative of the firm, will affect the brand reputation of the firm [1]. If the firm performs well in terms of CSR, it can establish a good image in society, express its compliance and positive externality to the government and the media, and enhance its good impression of the TMT [2]. Therefore, good performance of social responsibility by the TMT has become a goal for firms to establish a sense of collective honour.

The TMT being the most important decision makers in a firm, its decisions determine the strategic direction of the firm. Social responsibility is an aspect of a firm's overall strategy. Similar to innovation investment, brand building, and other strategies, it lays a foundation for the sustainable development of the firm. Under the limitations of the external environment and the firm's resources, how the TMT characteristics affect CSR has become a topic worthy of research [3]. The results based on the human capital and upper echelon theory reveal that corporate employees, especially TMT members, greatly affect the decision making in a firm and ultimately influence its long-term competitiveness [4,5]. In this process, CSR as a soft resource brings a positive social image [6] and this advantage 
is difficult for firms to imitate and establish in a short time. We summarise the current research on TMTs and CSR, which is mainly divided into two streams.

The first stream focuses on the relationship between individual executive characteristics and CSR; CEO change [7], including CEO characteristics [8,9]; and board member characteristics [10]. The second stream is TMT characteristics such as gender, tenure, age, and education [11,12] and the board structures [13]. These earlier studies closely examine the relationships between executives and CSR, but they have two deficiencies. First, when examining the relationship between CEO or chairman characteristics and CSR, they ignore the complex background behind the executives' fulfilment of CSR. Specifically, having limited energy, it is difficult for core executives to pay attention to the non-core business issues of CSR [14]. Second, although studies on TMTs and CSR supplement research on management decision making, they only consider the relationship between the characteristics of the TMT and CSR from a static perspective. Compared with the unusual changes in CEO, changes in ordinary executives occur often; so it is difficult for the TMT to have stable characteristics. Therefore, there may be bias in examining the relationship between the characteristics of the TMT and CSR. Thus, it is necessary to research the dynamic changes in the TMT for a more in-depth understanding.

Social responsibility is an important part of the sustainable development of a firm. Achievement of long-term benefits from socially responsible practices requires long-term capital investment [15], institutional continuity [16], and avoidance of practices that only bring short-term corporate financial performance (CFP) improvement [17]. However, because of information asymmetry, whether a firm is focused on long-term development is difficult to determine from outside the firm [18]. The sustainable development of a firm is greatly influenced by subtle interactions among stakeholders. As a bridge for communication among different stakeholders, the TMT is responsible for all aspects of decision making that consider profits for shareholders, fairness to employees, environmental protection, and consumers' welfare [19]. However, because of the view that emphasises the supremacy of shareholders' interests, the TMT does not focus on the long-term development of a firm when faced with force changes and resignation [20]. Rather, the TMT chooses to sacrifice environmental and consumer interests and reduce investment related to social responsibility to relieve pressure of short-term financial performance [21,22]. Meanwhile, when a TMT changes many members in a short time, it is difficult to inherit the original collective goals and establish a collective sense of honour. Managers struggle for their personal career, and it is difficult to consider the long-term sustainable development of the firms $[23,24]$.

Therefore, a change in TMT members over a period is used to measure the mobility of managers, that is, the TMT stability. Theoretically, a comparison between a firm with an unstable TMT and a stable TMT would show great differences in terms of tacit team understanding, flow of key information, and handling of performance pressure. Such factors influence the practices of the firm, and those that have an unstable TMT will eventually exhibit inconsistencies between the firms' sustainable development goals and CSR performance. Among Chinese listed firms, firms need to regularly disclose their performance of social responsibility according to regulations. For example, in 2006, the State Council of the People's Republic of China (PRC) included the level of local CSR in the performance evaluation criteria of local officials. In 2008, in order to enhance the awareness of corporate social responsibility, China's Shanghai and Shenzhen stock exchanges issued notices requiring a number of representative firms to forcibly disclose social responsibility reports. In 2017, the State Council of the PRC asked local officials to guide firms in actively fulfilling their social responsibilities, enhancing their sense of honour and mission in fulfilling their social responsibilities, offering love and care to employees, and protecting the ecology. We use the data of Hexun.com, a third-party corporate social responsibility evaluation organisation, to measure Chinese listed firms' CSR performance based on their CSR reports $[25,26]$. Influenced by Confucianism and socialism for a long time, China is still the representative of collectivism under the thought of Western capitalism [27]. 
Collectivism emphasises interpersonal interdependence, pays attention to interpersonal relations, emphasises harmonious coexistence among members, and works for common goals at the same time [28]. Culturally, as a representative of collectivism, China can form a collectivist TMT, which performs better in firm cooperation, which is reflected in its pursuit of the corporate image of "Charity and Harmony between Man and Nature". Therefore, it is of far-reaching significance to explore the formation of collectivism in the TMT in the context of Chinese culture. To be specific, the study examines the agency problem arising from different situations (early performance and slack resources) that influence this relationship, to provide an empirical reference for the applicable governance strategy that could help the firm achieve long-term development.

Our study makes several primary contributions to research. First, the study emphasises the importance of the stability of the TMT for the sustainable development of firms and the empirical results show that a stable TMT can promote better CSR performance. Second, existing discussions on the relationship between TMT and social responsibility based on upper echelon theory mostly start from a static perspective and do not consider the changes (turnover and succession) in the TMT. By considering this factor for a specific period, this study effectively enriches the application of the current upper echelon theory on the relationship between the TMT and CSR, and this also promotes dynamic TMT research. Third, this study enriches the literature on the relationship between TMT stability and CSR by examining how a firm's resources and post-performance, that is, performance aspiration gap and slack resources, affect CSR performance in a specific context. Our study analyses how a stable TMT with a different performance aspiration gap and slack resources makes its CSR strategy in the hope of untangling the agency problems. Finally, in the market with rapid technological innovation and high environmental uncertainty, firms integrate knowledge externally by rapidly changing managers to keep abreast of changing markets. However, it also leads to the difficulty of building a tacit understanding and the lack of collective atmosphere in the team. This study believes that through internal training and orderly integration of TMT, we can improve the sustainable development decision making of the team and provide available decision making for corporate governance.

\section{Literature Review and Hypotheses Development}

\subsection{Literature Review}

According to upper echelon theory, the heterogeneity (in terms of past experience, personality traits, and demographic characteristics [29]) of senior executives influences a firm's decision making on production processes and operations. Considering this theory in relation to this study's topic, whether a firm effectively practices social responsibility is closely related to the values of its senior executives. For example, the values formed from experience (CEOs' academic experience, functional department background, gender, tenure, and so on) influence the CSR performance $[16,30]$. Moreover, some special values, such as political consciousness [31], materialism [32], and self-confidence [33], have an impact. Furthermore, changes in the TMT composition, as a major change experienced by a firm, have different effects. For instance, data from the United States show that a change in CEO negatively affects CSR performance [34], while data from China shows that CEO succession improves a firm's CSR performance [7]. Moreover, upper echelon theory has been applied in TMT research. Earlier studies show that the heterogeneity and characteristics of the TMT are the two most relevant factors for the current research. Other studies show that the TMT pays great attention to the support of social ethics and strengthens the harmony between the TMT and the environment [35], as influenced by the TMT members' education and overseas experience [36] and tenure and gender [37,38]. Moreover, the diversity of the TMT personnel brings multiple perspectives to the team [26] and sharing social responsibility plays a role in easing the relationships among TMT members. At the same time, executives with different characteristics have different attitudes towards the long-term development of the firm. Executives who consider the long-term development of a firm pay more attention to the improvement of the firm's future performance and thus focus on strategies 
that may not result in short-term benefits but are favourable in the long term, such as good supply chain and customers relations [39], environment-friendly innovation [40], and the fulfilment of social responsibility [15]. Having such a long-term performance focus requires that the firm not be concerned about lower performance in the present and have considerable resources to meet unstable income in the future. Although current analyses of the TMT's characteristics improve on the one-sidedness of previous analyses that consider only a single executive's characteristics and experiences and the current analyses enrich the role of the TMT as a decision-making team in the firms [14,29], these analyses take a static perspective. Changes in TMT personnel occur more frequently than changes in core personnel, such as the CEO or chairman; this consequently modifies the characteristics of the TMT. Therefore, it is necessary to analyse the impact of the overall variability of the TMT on the overall sustainable development of a firm from a dynamic perspective.

Theoretically, exploring the overall variability of the TMT can provide, to a certain extent, insights into the current development and decision-making views of the firm. On the one hand, the development of a firm can be considered speculative in that the firm that can realise cash in the short term pays more attention to marketing [41] and iteration of technology integration [42], so as to quickly enter relevant markets, occupy a niche in the market, and reap the corresponding benefits. Once the business situation changes, the investment is immediately withdrawn, the relevant department is dissolved, and the senior executives are dismissed. Firms that focus on cultivating the market and intend to operate in the market for a longer timeframe pay more attention to developing the relevant talents [43] and continuously invest the necessary resources to promote the firm's long-term development. On the other hand, decisions made by a firm in response to the external environment affect the business situation of the firm, especially the decision making of the TMT. Compared with a firm that focuses on long-term development, one that focuses on short-term interests pays more attention to short-term tactical adjustments when a long-term sustainable strategy is relatively more difficult, and in this case, the consistency before and after a decision is made is even less [44], which is reflected in frequent changes in personnel positions within the firms. Compared with other personnel changes, those within the TMT have a stronger impact on the decision-making and development views within the firm because of the team members' particularity. Internal and external personnel can reflect on the utilitarian and sustainable development plans of the firm by observing the change frequency among the TMT [43]. The variability of senior executives may also reflect whether a firm truly appreciates talent, rather than simply focusing on the personnel's immediate contribution, and may also indicate whether the firm values longterm, sustainable development.

\subsection{Hypotheses Development}

When the handover between outgoing and incoming TMT members is executed properly, the range of change in task outcomes related to that position is small. This ensures continuation in team atmosphere as well. Furthermore, a state of stability is evident. On the contrary, when many managers change in a short time, there will be an atmosphere of panic, short-sighted behaviour, and reduced strategic behaviour [45]. At this time, the TMT is in an unstable state. As a long-term strategic investment, CSR brings corporate financial performance (CFP) to firms [46], improves consumer loyalty [47], and reduces the sudden decline in performance caused by negative behaviour [48]. Considering the CSR benefits, this study proposes that a stable TMT serves as a foundation for developing efficient management skills, thereby allowing integration of information, balancing of various stakeholder interests, reduction of asymmetries in rights and responsibilities, and improvements in the performance of social responsibility.

First, a stable TMT has formed a tacit understanding with a good cooperation atmosphere and has a sense of collective honour. Moreover, through long-term cooperation, the TMT can form lines of communication with all parties, resulting in the rapid transmission of information. To succeed, a firm's strategy requires a long-term investment and 
continuity [49]. Continuously updated information flow can bring clear external environmental information and organisational resource information to a firm, which helps in the formulation of a strategy that is more in line with the social environment and available resources [50,51]. The unique communication mode formed by a stable TMT takes time to establish. As a country with strong collectivism, it is easier for China to form a working atmosphere with a sense of collective honour in a stable TMT. This atmosphere makes the TMT pay more attention to the collective image and maintain the collective reputation [52]. In the unstable TMT, due to the large number of personnel changes, the collective atmosphere is difficult to inherit, with a frequent change in members, and advocates fighting among individuals. CSR can create a good image for the firm, establish brand reputation, and allow the senior management team to develop a good reputation [1,7]. In a less stable TMT, due to the short stay of personnel, they fail to form a tacit understanding [53], thus reducing the efficiency of communications. CSR is oriented towards stakeholders such as employees, society, and the environment; timely communication is necessary to position the firm's resources appropriately [54].

Second, while respecting the interests of shareholders, a stable TMT will also pay attention to stakeholders and seek benefits for the environment, employees, and consumers. When a firm changes a large number of executive members, the newly added managers will be dismissed for fear of lack of legitimacy [7] and the remaining executives will focus on short-term performance to avoid dismissal [55]. As a non-main assessment item, CSR is not regarded as a key focus. At the same time, fulfilment of social responsibility is a longterm project and the stability of financial performance income is low [56], and sometimes, CSR has a negative impact on financial performance $[57,58]$. Therefore, it is impractical for new executives to focus on CSR. Moreover, to reduce the threat of dismissal, new executives care more about CFP than CSR performance [59]. As such, in a TMT with low stability, the members face greater pressure on CFP and are more inclined to reduce focus on social responsibility, to seek improvement in financial performance. In the long-term cooperation process, a stable TMT forms a tacit understand and the members respect each other's interest. Compared with firms that have an unstable TMT, those with a stable TMT face lower financial performance pressure, and the TMTs focus more on the long-term development of the firm and the rights and interests of relevant stakeholders [60].

Finally, in firms with a stable TMT, the division of responsibility and power is relatively clear; as such, the prevarication of responsibility when placing blame is reduced and the responsible person pays more attention to fulfilling social responsibility. In a TMT with low stability, due to the frequent personnel turnover, a certain degree of overlap and omission in the implementation and task arrangement among senior managers is common, resulting in errors in terms of right and responsibility allocation, reduced team cohesion [51], and difficulty in completing the final task. Social responsibility is a marginal task in a firm [61]; thus, it is more prone to mismatch when TMT stability is low. It is also difficult to find the responsible person after an incident, which impacts the completion of follow-up tasks. In firms with a stable TMT, when the responsibilities and rights are relatively clear, senior managers can do their best to complete their duties. They can also identify the responsible person when performance is poor, improve the quality of decision making, and complete the strategic objectives [62]. Activities concerning social responsibility may be considered unnecessary and yet be a high moral requirement; as such, there is a tendency to place blame. When the performance of social responsibility is poor in a firm with a stable TMT, it is more difficult for TMT members to avoid their responsibility because of the effect on public relations. Meanwhile, in firms with an unstable TMT, the performance of social responsibility is poor, the members may place blame on the previous senior managers, the TMT may not be able to avoid a negative situation with its lack of understanding of the current social performance, and the public might increase its criticism. Based on the analysis above, this study proposes that TMT stability is an important factor affecting CSR performance: 
Hypotheses 1 (H1). TMT stability has a positive impact on the CSR performance.

It further proposes that the effects of TMT stability on CSR performance are not homogeneous and both resource endowment and early financial performance influence the relationship between TMT stability and CSR performance. Specifically, given the same level of TMT stability, different firm characteristics lead to different levels of CSR performance. Considering these factors, this study further investigates the mechanism of the relationship between TMT stability and CSR performance, mainly from the aspects of early performance (performance aspiration gap) and resource endowment (slack resources).

The performance aspiration gap arises from the difference between the actual performance and the target performance. When the actual performance is higher than the target performance, this is called a performance aspiration surplus, and when it is lower, it is called a performance aspiration deficit [63]. Different aspiration performance measurement standards are important for measuring the final state. On the one hand, a firm needs to consider its historical development factors to measure its status [63]; on the other hand, a comparison with the development level of the industry can show the competitive state of a firm [64]. Based on these two considerations, we can measure the current state of a firm more accurately. Because of performance aspiration, the surplus and deficit will affect the judgement of the TMT regarding the current operations [63] and the shareholders have priorities that differ from those of senior management. Therefore, given TMT stability at similar levels, the willingness of the TMT to perform social responsibility will vary under different early performance states.

When the early performance of a firm is characterised by a surplus of performance aspiration, the actual performance "exceeds" the performance expectations and the senior executives determine the status as a "gain" that proves that the previous business strategy was effective, thereby establishing their legitimacy [65], and the shareholders recognise the TMT's performance. Social responsibility serves as the link between the stakeholders. When the TMT completes a task, even if it performs poorly in its social responsibility, this is hardly a reason for dismissal. Relevant studies also show that the main reason for the dismissal of executives is low financial performance [66]. In other words, executives with insufficient ability are dismissed by the governance team [18]. Moreover, this performance aspiration surplus increases the senior executives' reliance on favour and arrogance and encourages self-interest with the knowledge of delivering on financial performance. When there is a performance aspiration deficit, the organisational state is considered a "loss". In such a state, the governance team exerts pressure on the TMT. In addition to strategic change [67], the TMT needs to reduce the pressure brought by shareholders in donation. As a strategy to cushion the pressure, fulfilling CSR can show goodwill to stakeholders; it can be employed as a marketing strategy [68] to enable subsequent performance improvement and address character-related risks [69]. In summary, given similar levels of TMT stability, the pressure faced by the TMT attributable to performance aspiration surplus or deficit would differ, resulting in differences in the motivation to perform social responsibility. Therefore, this study proposes that:

Hypotheses 2 (H2). In firms with a performance aspiration surplus, the relationship between TMT stability and CSR performance is weakened.

Slack resources are resources that are left in the firm after the current actual needs of the firm are met [70]. According to the organisation theory, slack resources can allow firms to offset part of the external impact on the organisation in the face of difficulties, thereby having a buffer effect [71]. They can also enable transformation when the organisation needs resources to provide support for the organisation's strategy [72]. However, agency theory holds that slack resources, as resources that have not been maximised, are controlled by the TMT when left in the organisation, which makes it easy for senior managers to abuse resources to gain job benefits [73] and engage in managerial empire building [74]. Meanwhile, other studies show that slack resources can easily lead to low firm management 
efficiency [75]. Both slack and mismatched resources lead to the failure of the firm to achieve the best operational efficiency, resulting in the reduction of resources applied to fulfil social responsibility [76]. According to the pyramid model of social responsibility, firms are willing to perform higher-level social responsibility only after meeting their economic responsibility [61]. Although having slack resources enables a firm to avoid risks to a certain extent, there are associated costs, such as waste of resources and exposure to the self-interest of executives. As such, resources that should have been used to fulfil social responsibility remain in the organisation, resulting in a waste of resources. Therefore, this study proposes that:

Hypotheses 3 (H3). In firms with abundant slack resources, the relationship between TMT stability and CSR performance is weakened.

\section{Materials and Methods}

\subsection{Data and Sample}

This study selects A-share listed firms in Shanghai and Shenzhen from 2010 to 2019 as the initial sample. To ensure the representativeness of the sample, the following firms are excluded: (1) delisted firms, (2) financial and insurance firms, because the business attributes of financial and insurance firms are quite different from those of other firms, and (3) those with missing data. The final sample contains 23,084 firm/year data. The main data came from the China Stock Market Accounting Research and Hexun.com; they were verified and checked against the Wind database and the annual reports and processed using the software Stata 14.0. The impact of outliers on the overall data was removed. In this study, all continuity variables were winsorised at $1 \%$ and $99 \%$. Table 1 shows the sample distribution by year and industry.

Table 1. Sample distribution by industry and year.

\begin{tabular}{|c|c|c|c|c|c|c|c|c|c|c|c|}
\hline Industry/Year & 2010 & 2011 & 2012 & 2013 & 2014 & 2015 & 2016 & 2017 & 2018 & 2019 & Total \\
\hline Agriculture/Forestry/Farming/Fishery & 24 & 34 & 29 & 32 & 33 & 34 & 37 & 36 & 35 & 36 & 330 \\
\hline Mining/Metallurgy & 40 & 49 & 52 & 53 & 57 & 63 & 64 & 66 & 69 & 71 & 584 \\
\hline Food/Textiles & 105 & 132 & 145 & 151 & 152 & 159 & 166 & 178 & 198 & 199 & 1585 \\
\hline Furniture/Chemicals/Pharmaceuticals & 283 & 340 & 391 & 406 & 407 & 420 & 443 & 504 & 582 & 605 & 4381 \\
\hline Machinery/Equipment & 470 & 622 & 749 & 805 & 827 & 869 & 941 & 1029 & 1193 & 1225 & 8730 \\
\hline Other Manufacturing & 24 & 31 & 27 & 34 & 36 & 41 & 47 & 55 & 61 & 62 & 418 \\
\hline Utilities/Energy & 52 & 53 & 57 & 56 & 60 & 68 & 76 & 79 & 81 & 84 & 666 \\
\hline Architectural/Construction & 29 & 36 & 50 & 54 & 56 & 60 & 65 & 77 & 79 & 79 & 585 \\
\hline Wholesale/Retail & 88 & 102 & 126 & 129 & 124 & 126 & 129 & 138 & 143 & 148 & 1253 \\
\hline Transportation/Logistic/Distribution & 38 & 41 & 45 & 54 & 55 & 57 & 62 & 66 & 74 & 78 & 570 \\
\hline Hospitality/Restaurant/Food Services & 9 & 9 & 10 & 10 & 10 & 10 & 8 & 8 & 8 & 8 & 90 \\
\hline Telecom Operators/Service Providers & 66 & 95 & 100 & 118 & 128 & 134 & 163 & 201 & 233 & 246 & 1484 \\
\hline Real Estate Development & 106 & 112 & 125 & 118 & 116 & 115 & 113 & 109 & 111 & 109 & 1134 \\
\hline Property Management & 16 & 24 & 19 & 19 & 21 & 20 & 35 & 38 & 46 & 48 & 286 \\
\hline Science Research/Technology Services & 6 & 9 & 10 & 12 & 11 & 17 & 21 & 26 & 44 & 49 & 205 \\
\hline Public Facilities Management & 4 & 5 & 22 & 24 & 26 & 28 & 31 & 34 & 43 & 45 & 262 \\
\hline Entertainment/Leisure/Sports and Fitness & 8 & 14 & 20 & 22 & 23 & 32 & 36 & 43 & 53 & 54 & 305 \\
\hline Conglomerates & 39 & 42 & 17 & 17 & 17 & 18 & 19 & 17 & 16 & 14 & 216 \\
\hline Total & 1407 & 1750 & 1994 & 2114 & 2159 & 2271 & 2456 & 2704 & 3069 & 3160 & 23,084 \\
\hline
\end{tabular}

\subsection{Variable Description}

\subsubsection{Dependent Variable}

Corporate social responsibility performance (CSR score): This study selects the CSR score provided by Hexun.com (Hexun's CSR score announcement website: http:/ / stockdata. stock.hexun.com/zrbg/Plate.aspx?date=2010-12-31 (accessed on 29 July 2021)) as a proxy variable for CSR performance [25,26]. Since 2010, Hexun.com has taken the CSR report, disclosure, and financial statements of firms as a reference, comprising 5 major items, shareholder, society, employee, customer and consumer's right and interests, and environmental; 
13 secondary indicators; and 37 tertiary indicators to jointly measure the CSR performance of a listed firm in a given year [26]. The better you perform in this sub-indicator, the higher the score of this sub-indicator [77]. Therefore, if a firm has a high total score, its overall CSR performance is better [25].

\subsubsection{Independent Variable}

TMT stability (TMTS): This study selects the stability coefficient to measure the stability of the TMT [78]. TMT is defined in this study as all senior executives except independent directors and independent supervisors, including the chairman, the CEO, and other leaders involved in management. The components of Equation (1) below are as follows: TMTStability ${ }_{t-1, t}$ is the stationary coefficient; $\#\left(S_{t-1} \backslash S_{t}\right)$ indicates the number of executives who are in the firm at time $t-1$ but not in the firm at time $t ; n\left(S_{t} \backslash S_{t-1}\right)$ refers to the number of executives in the firm at time $t$ but not at time $t-1 ; M_{t-1}$ represents the total number of executives in the firm at time $t-1$; and $M_{t}$ represents the total number of executives in the firm at time $t$. Based on the above, TMTStability $y_{t-1, t}$ is a value between $(0,1)$, and the closer the value is to 1 , the higher the TMT stability. The stationary coefficient is calculated as follows:

TMTStability $_{\mathrm{t}-1, \mathrm{t}}=\frac{\mathrm{M}_{\mathrm{t}-1}-\#\left(\mathrm{~S}_{\mathrm{t}-1} \backslash \mathrm{S}_{\mathrm{t}}\right)}{\mathrm{M}_{\mathrm{t}-1}} \times \frac{\mathrm{M}_{\mathrm{t}}}{\mathrm{M}_{\mathrm{t}-1}+\mathrm{M}_{\mathrm{t}}}+\frac{\mathrm{M}_{\mathrm{t}}-\#\left(\mathrm{~S}_{\mathrm{t}} \backslash \mathrm{S}_{\mathrm{t}-1}\right)}{\mathrm{M}_{\mathrm{t}}} \times \frac{\mathrm{M}_{\mathrm{t}-1}}{\mathrm{M}_{\mathrm{t}-1}+\mathrm{M}_{\mathrm{t}}}$

For example, a firm had a TMT of 20 people in $\mathrm{t}-1$. In $\mathrm{t}$ year, due to the resignation and recruitment of senior executives, the number of TMT increased to 25, of which 15 were unchanged during this period. Through the definition of Equation (1), we can get $\mathrm{M}_{\mathrm{t}-1}=20, \mathrm{M}_{\mathrm{t}}=25, \#\left(\mathrm{~S}_{\mathrm{t}-1} \backslash \mathrm{S}_{\mathrm{t}}\right)=5$, and $\#\left(\mathrm{~S}_{\mathrm{t}} \backslash \mathrm{S}_{\mathrm{t}-1}\right)=10$; Final TMTStability $\mathrm{t}_{\mathrm{t}-1, \mathrm{t}}=0.889$.

Performance aspiration gap (aspiration gap): This refers to the difference between actual performance and aspiration performance. This study measures performance aspiration gap according to previous studies [79-82] and divides performance aspiration into two parts, industry performance aspiration (indasp) and historical performance aspiration (hisasp), which are calculated using the equation below.

The performance measurement index is the rate of return on total assets (ROA) [82]. Equation (2) shows that the performance aspiration of firm $i$ in year $t$ is composed of two parts: industry performance aspiration Ind $A s p_{i, t}$ and historical performance aspiration His Asp $p_{i, t}\left(\mathrm{t} \geq 3\right.$. When $\mathrm{t}=3$, Ind Asp $p_{i, 1}=$ Real IndRoa $\left._{i, 1}\right)$, where $\alpha_{1}$ represents the weight level, following a previous study [81], which is taken as 0.5. Equation (3) shows that the industry performance aspiration of industry $i$ in year $t$ is increased by the industry performance aspiration of the previous year Ind $A s p_{i, t-1}$ and the actual industry performance of the previous year Real IndRoa $a_{i, t-1}$. Where the industry performance aspiration is equal to the average of the ROA of the industry, the industry classification standards follow the China Securities Regulatory Commission in 2012 (The Guidelines for the Industry Classification of Listed Companies (2012 Revision): http:/ / www.csrc.gov.cn/pub / csrc_en/ /laws / overRule/Announcement/201302/t20130225_221587.html (accessed on 5 December 2021)). $\beta_{1}$ represents the weight level, following a previous study [82], which is taken as 0.6 , and historical performance aspiration is calculated in the same way as industry performance aspiration.

$$
\begin{aligned}
& A s p_{i, t}=\left(1-\alpha_{1}\right) \operatorname{Ind} A s p_{i, t}+\alpha_{1} H i s A s p_{i, t} \\
& \operatorname{Ind} A s p_{i, t}=\left(1-\beta_{1}\right) \operatorname{Ind} A s p_{i, t-1}+\beta_{1} \operatorname{RealIndRoa}_{i, t-1}
\end{aligned}
$$

Slack resources: This study follows Bourgeois's [70] definition of slack resources and takes the average of potential slack (the ratio of total owners' equity to total liabilities), absorbed slack (the ratio of the sum of management expenses and sales expenses to operating revenue), and unabsorbed slack (the ratio of current assets to current liabilities). 


\subsubsection{Control Variables}

According to previous studies on social responsibility performance, this study sets the following four categories of control variables: organisation characteristics, organisation operation, board structure, and TMT characteristics.

Organisation characteristics includes state-owned enterprise (SOE), firm age, and firm size. SOE indicates the type of enterprise ownership. When the firm is an SOE, it is 1, but it is 0 otherwise. Research shows that the social responsibility of an SOE is better than that of a non-SOE [83]. Firm age represents the natural logarithm of the listing age plus 1 , and the older a firm, the better the CSR performance [84]. Firm size refers to the size of the firm, which is the natural logarithm of the fixed assets of the firm in the current year; the larger the firm scale, the better the social responsibility [58].

Organisation operation includes asset debt ratio and firm growth. The asset in the asset debt ratio refers to fixed assets; the larger the asset ratio, the better the CSR performance [85]. We use the growth rate of sales to measure firm growth; the greater the firm growth, the better the CSR performance [86].

Board structure includes Top 1 rate, independent ratio, board size, and dual. We use Top1 rate to represent the share proportion of the largest shareholder. In state-owned enterprises and private enterprises, different degrees of ownership dispersion have the opposite effect on CSR [87]. Independent ratio represents the proportion of independent directors in all directors. The proportion of independent directors will also promote the performance of CEO tenure and social and environmental disclosure [88]. Board size is measured by the natural logarithm of the number of directors. Dual implies that the same person acts as CEO and chairman, in which case it is 1 , but it is 0 otherwise. The size of the board of directors and separation of the $\mathrm{CEO}$ and chairman roles have a positive impact on CSR [89].

TMT characteristics includes TMT average age and TMT male ratio. We use the average age of TMT and the proportion of TMT men as proxy variables to test the impact of executive team characteristics on CSR $[11,90]$.

This study also sets the year and industry dummy variables, in which industry classification refers to the industry classification in 2012.

Table 2 shows the descriptive statistics of all variables in this study.

Table 2. Summary statistics.

\begin{tabular}{cccccccc}
\hline Variable & $N$ & Mean & SD & Min & p50 & Max \\
\hline CSR score & 23,084 & 24.72 & 16.03 & -3.28 & 21.99 & 74.88 \\
TMTS & 23,084 & 0.89 & 0.076 & 0.636 & 0.899 & 1 \\
Aspiration gap & 23,084 & 0.092 & 0.354 & -0.735 & 0.026 & 1.902 \\
Slack resources & 23,084 & 1.696 & 1.852 & 0.246 & 1.062 & 11.59 \\
SOE & 23,084 & 0.385 & 0.487 & 0 & 0 & 1 \\
Firm age & 23,084 & 2.826 & 0.351 & 1.609 & 2.89 & 3.466 \\
Firm size & 23,084 & 22.16 & 1.291 & 19.8 & 21.98 & 26.15 \\
Asset debt ratio & 23,084 & 0.664 & 0.454 & 0.077 & 0.558 & 2.657 \\
Growth & 23,084 & 0.448 & 1.268 & -0.669 & 0.144 & 9.631 \\
Top1 rate & 23,084 & 34.9 & 14.88 & 8.8 & 32.97 & 74.82 \\
Independent ratio & 23,084 & 0.375 & 0.054 & 0.333 & 0.333 & 0.571 \\
Board size & 23,084 & 2.249 & 0.177 & 1.792 & 2.303 & 2.773 \\
Dual & 23,084 & 0.26 & 0.439 & 0 & 0 & 1 \\
TMT average age & 23,084 & 49.06 & 3.127 & 41.39 & 49.14 & 56.38 \\
TMT male ratio & 23,084 & 0.819 & 0.108 & 0.526 & 0.833 & 1 \\
\hline
\end{tabular}

\section{Results and Analysis}

\subsection{Regression Results}

Table 3 shows the Pearson correlation matrix and the descriptive statistics of the variables in this study. The correlation coefficients between variables were less than 0.6 , which preliminarily indicated the absence of multicollinearity. The variance expansion 
factor test revealed that the coefficient was far less than 10, indicating that multicollinearity did not exist. Referring to the correlation matrix, the correlation coefficient between CSR score and the TMTS was $0.084(p<0.01)$.

Table 3. Correlation matrix.

\begin{tabular}{|c|c|c|c|c|c|c|c|c|}
\hline Variables & 1 & 2 & 3 & 4 & 5 & 6 & 7 & 8 \\
\hline 1. CSR score & / & & & & & & & \\
\hline 2. TMTS & $0.084^{* * *}$ & 1.05 & & & & & & \\
\hline 3. Aspiration gap & $0.160 * * *$ & $0.058 * * *$ & 1.04 & & & & & \\
\hline 4. Slack resources & $0.016^{* *}$ & $0.079 * * *$ & $0.135 * * *$ & 1.26 & & & & \\
\hline 5. SOE & $0.132 * * *$ & $-0.078^{* * *}$ & $-0.022^{* * *}$ & $-0.231^{* * *}$ & 1.42 & & & \\
\hline 6. Firm age & $-0.063 * * *$ & $-0.081^{* * *}$ & $-0.115^{* * *}$ & $-0.166^{* * *}$ & $0.182 * * *$ & 1.16 & & \\
\hline 7. Firm size & $0.282^{* * *}$ & $-0.065^{* * *}$ & $-0.092^{* * *}$ & $-0.378 * * *$ & $0.344^{* * *}$ & $0.165^{* * *}$ & 1.48 & \\
\hline 8. Asset debt ratio & $0.083^{* * *}$ & $0.016^{* *}$ & 0.005 & $-0.192 * * *$ & $0.079 * * *$ & $-0.013^{* *}$ & $0.061^{* * *}$ & 1.08 \\
\hline 9. Growth & $0.029 * * *$ & $-0.046^{* * *}$ & $-0.011 *$ & $-0.032 * * *$ & $0.029 * * *$ & $0.058^{* * *}$ & $0.025^{* * *}$ & $-0.143^{* * *}$ \\
\hline 10. Top1 rate & $0.147^{* * *}$ & 0.004 & $0.018^{* * *}$ & $-0.051^{* * *}$ & $0.225^{* * *}$ & $-0.105^{* * *}$ & $0.212^{* * *}$ & $0.087^{* * *}$ \\
\hline 11.Independent ratio & $-0.011^{*}$ & $-0.034^{* * *}$ & $-0.034^{* * *}$ & $0.011 *$ & $-0.052^{* * *}$ & $-0.022^{* * *}$ & $0.024^{* * *}$ & $-0.035^{* * *}$ \\
\hline 12. Board size & $0.140 * * *$ & $0.023 * * *$ & $0.028 * * *$ & $-0.124 * * *$ & $0.261 * * *$ & $0.026^{* * *}$ & $0.258 * * *$ & $0.044^{* * *}$ \\
\hline 13. Dual & $-0.065^{* * *}$ & $0.036^{* * *}$ & 0.002 & $0.132 * * *$ & $-0.297 * * *$ & $-0.094^{* * *}$ & $-0.181^{* * *}$ & $-0.046^{* * *}$ \\
\hline 14. TMT average age & $0.088^{* * *}$ & $0.112 * * *$ & $-0.058^{* * *}$ & $-0.148^{* * *}$ & $0.344^{* * *}$ & $0.209 * * *$ & $0.356^{* * *}$ & $0.034^{* * *}$ \\
\hline 15. TMT male ratio & $0.075^{* * *}$ & $0.023^{* * *}$ & $0.011 *$ & $-0.126^{* * *}$ & $0.236^{* * *}$ & $-0.045^{* * *}$ & $0.188^{* * *}$ & $0.047^{* * *}$ \\
\hline Variables & 9 & 10 & 11 & 12 & 13 & 14 & 15 & \\
\hline 9. Growth & 1.03 & & & & & & & \\
\hline 10. Top1 rate & $0.015^{* *}$ & 1.13 & & & & & & \\
\hline 11.Independent ratio & $0.019 * * *$ & $0.048 * * *$ & 1.45 & & & & & \\
\hline 12. Board size & $-0.023^{* * *}$ & $0.026^{* * *}$ & $-0.523^{* * *}$ & 1.63 & & & & \\
\hline 13. Dual & $-0.024^{* * *}$ & $-0.048^{* * *}$ & $0.113^{* * *}$ & $-0.183^{* * *}$ & 1.13 & & & \\
\hline 14. TMT average age & $-0.025^{* * *}$ & $0.130^{* * *}$ & $-0.028^{* * *}$ & $0.217^{* * *}$ & $-0.177^{* * *}$ & 1.35 & & \\
\hline 15. TMT male ratio & $-0.029^{* * *}$ & $0.068^{* * *}$ & $-0.065^{* * *}$ & $0.177^{* * *}$ & $-0.128^{* * *}$ & $0.249^{* * *}$ & 1.14 & \\
\hline
\end{tabular}

Note: $N=23,084{ }^{* * *},{ }^{* *}$, and ${ }^{*}$ denote significance at the 1,5 , and $10 \%$ levels, respectively. The diagonal values in the matrix denote the variance inflation factor (VIF); the mean VIF is 1.24 .

To avoid the problems of heteroscedasticity, autocorrelation, and cross-section correlation caused by panel data, this study used the Driscoll-Kraay standard error for regression analysis [91] and simultaneously controlled for the year and industry effects. To avoid endogeneity, the fixed effect of firms was added to reduce the biased estimation caused by omission bias.

In Table 4, Model 1, as a benchmark regression, contained the regression coefficient of the control variable. In the control variables, there are two inconsistent with the previous expectations, namely, SOE and firm age. This study expects that CSR will perform better in SOE, and the older the listing age of firms, the better the performance of social responsibility. However, the results of this study are on the contrary (SOE: $\beta=-1.218, p<0.05$; firm age: $\beta=-3.759, p<0.05)$. The possible reason is that the scale of SOE and the older firm is larger, they have legitimacy in the eyes of the government and public, and there is no motivation to conduct their social responsibilities [92]. Board size, dual, TMT average age, and TMT male ratio are not significant, but others are consistent with expectations.

Model 2, based on Model 1 and with TMT stability added, generated a significantly positive $(\beta=5.409, p<0.01)$ result, thus supporting Hypothesis 1 . The small economic effect (just $2.6 \%$ ) of TMTS is mainly due to the small time span of our measurement of TMTS, the limited number of changes in TMT, and many influencing factors on CSR. Model 3, based on Model 2 and with the interaction items of performance aspiration gap and TMT stability (TMTS $\times$ aspiration gap) added, generated a significantly negative $(\beta=-13.938, p<0.01)$ value for the interaction item, thus supporting Hypothesis 2 . Model 4, based on Model 2 and with the slack resources and the interaction term between slack resources and TMT stability (TMTS $\times$ slack resources) added, generated a significantly negative $(\beta=-2.914$, $p<0.01$ ) value for the interaction item, thus supporting Hypothesis 3 . Finally, Model 5 generated consistent results when all variables were included in the comprehensive model, indicating robustness of the results. 
Table 4. Regression result.

\begin{tabular}{|c|c|c|c|c|c|}
\hline Variables & Model 1 & Model 2 & Model 3 & Model 4 & Model 5 \\
\hline TMTS & & $\begin{array}{c}5.409 * * * \\
(0.787)\end{array}$ & $\begin{array}{c}7.097^{* * *} \\
(0.823)\end{array}$ & $\begin{array}{c}9.810 * * * \\
(1.454)\end{array}$ & $\begin{array}{c}10.858^{* * *} \\
(1.641)\end{array}$ \\
\hline Aspiration gap & & & $\begin{array}{c}15.625^{* *} \\
(4.847)\end{array}$ & & $\begin{array}{c}14.484^{* *} \\
(4.844)\end{array}$ \\
\hline TMTS $\times$ Aspiration gap & & & $\begin{array}{c}-13.938^{* * *} \\
(3.533)\end{array}$ & & $\begin{array}{c}-12.846^{* * *} \\
(3.544)\end{array}$ \\
\hline Slack resources & & & & $\begin{array}{c}3.293^{* * *} \\
(0.498)\end{array}$ & $\begin{array}{c}2.923^{* * *} \\
(0.669)\end{array}$ \\
\hline TMTS $\times$ Slack sources & & & & $\begin{array}{c}-2.914^{* * *} \\
(0.577)\end{array}$ & $\begin{array}{c}-2.576^{* * *} \\
(0.721)\end{array}$ \\
\hline SOE & $\begin{array}{c}-1.218 \text { ** } \\
(0.476)\end{array}$ & $\begin{array}{c}-1.219 \text { ** } \\
(0.461)\end{array}$ & $\begin{array}{c}-1.143^{* *} \\
(0.429)\end{array}$ & $\begin{array}{l}-1.100 * * \\
(0.475)\end{array}$ & $\begin{array}{c}-1.039 \text { ** } \\
(0.448)\end{array}$ \\
\hline Firm age & $\begin{array}{c}-3.759 * * \\
(1.304)\end{array}$ & $\begin{array}{c}-3.582 * * \\
(1.339)\end{array}$ & $\begin{array}{c}-3.281 * * \\
(1.208)\end{array}$ & $\begin{array}{l}-1.679 \\
(1.304)\end{array}$ & $\begin{array}{l}-1.575 \\
(1.252)\end{array}$ \\
\hline Firm size & $\begin{array}{c}4.417^{* * * *} \\
(0.509)\end{array}$ & $\begin{array}{c}4.437^{* * *} \\
(0.513) \\
\end{array}$ & $\begin{array}{c}4.441^{* * *} \\
(0.494)\end{array}$ & $\begin{array}{c}4.771^{* * *} \\
(0.489)\end{array}$ & $\begin{array}{c}4.741^{* * * *} \\
(0.492)\end{array}$ \\
\hline Asset debt ratio & $\begin{array}{c}6.019 * * * \\
(0.472)\end{array}$ & $\begin{array}{c}6.019^{* * *} \\
(0.480)\end{array}$ & $\begin{array}{c}5.876^{* * *} \\
(0.396)\end{array}$ & $\begin{array}{c}6.601 * * * \\
(0.466)\end{array}$ & $\begin{array}{c}6.409^{* * *} \\
(0.391)\end{array}$ \\
\hline Growth & $\begin{array}{c}0.260^{* * *} \\
(0.077)\end{array}$ & $\begin{array}{c}0.266^{* * *} \\
(0.076)\end{array}$ & $\begin{array}{c}0.236^{* * *} \\
(0.062)\end{array}$ & $\begin{array}{c}0.280 * * * \\
(0.076)\end{array}$ & $\begin{array}{c}0.250 * * * \\
(0.062)\end{array}$ \\
\hline Top1 rate & $\begin{array}{c}0.043^{* * *} \\
(0.009)\end{array}$ & $\begin{array}{c}0.043^{* * *} \\
(0.009)\end{array}$ & $\begin{array}{c}0.041^{* * *} \\
(0.008)\end{array}$ & $\begin{array}{c}0.043^{* * *} \\
(0.008)\end{array}$ & $\begin{array}{c}0.041^{* * *} \\
(0.007)\end{array}$ \\
\hline Independent ratio & $\begin{array}{l}7.473 * \\
(3.616)\end{array}$ & $\begin{array}{l}7.532 * \\
(3.573)\end{array}$ & $\begin{array}{l}8.115^{* *} \\
(3.308)\end{array}$ & $\begin{array}{l}7.718 * \\
(3.567)\end{array}$ & $\begin{array}{l}8.249 * * \\
(3.318)\end{array}$ \\
\hline Board size & $\begin{array}{c}1.621 \\
(1.100)\end{array}$ & $\begin{array}{c}1.563 \\
(1.072)\end{array}$ & $\begin{array}{c}1.701 \\
(1.078)\end{array}$ & $\begin{array}{c}1.424 \\
(1.068) \\
\end{array}$ & $\begin{array}{c}1.568 \\
(1.071)\end{array}$ \\
\hline Dual & $\begin{array}{l}-0.521 \\
(0.291)\end{array}$ & $\begin{array}{c}-0.531 * \\
(0.286)\end{array}$ & $\begin{array}{c}-0.541 * \\
(0.281)\end{array}$ & $\begin{array}{c}-0.591 * \\
(0.292)\end{array}$ & $\begin{array}{c}-0.595 * \\
(0.287)\end{array}$ \\
\hline TMT average age & $\begin{array}{l}-0.102 \\
(0.058)\end{array}$ & $\begin{array}{c}-0.160 \text { ** } \\
(0.061)\end{array}$ & $\begin{array}{c}-0.153 \text { ** } \\
(0.062)\end{array}$ & $\begin{array}{c}-0.144^{* *} \\
(0.062)\end{array}$ & $\begin{array}{c}-0.140 * \\
(0.063)\end{array}$ \\
\hline TMT male ratio & $\begin{array}{c}1.794 \\
(1.691)\end{array}$ & $\begin{array}{l}1.740 \\
(1.685)\end{array}$ & $\begin{array}{c}1.486 \\
(1.711)\end{array}$ & $\begin{array}{c}1.803 \\
(1.626)\end{array}$ & $\begin{array}{l}1.557 \\
(1.659)\end{array}$ \\
\hline Constant & $\begin{array}{c}-67.881^{* * *} \\
(13.664)\end{array}$ & $\begin{array}{c}-70.594^{* * *} \\
(13.568)\end{array}$ & $\begin{array}{c}-74.169^{* * *} \\
(11.667)\end{array}$ & $\begin{array}{c}-89.068^{* * *} \\
(12.950)\end{array}$ & $\begin{array}{c}-90.536^{* * *} \\
(12.207)\end{array}$ \\
\hline Year/Industry & YES & YES & YES & YES & YES \\
\hline Within $\mathrm{R}^{2}$ & 0.176 & 0.176 & 0.184 & 0.181 & 0.187 \\
\hline $\mathrm{F}$ & $131.9^{* * *}$ & $989.4^{* * *}$ & $99.66^{* * *}$ & $49.31 * * *$ & $83.91^{* * *}$ \\
\hline
\end{tabular}

Notes: $N=23,084 .^{* * *}, * *$, and ${ }^{*}$ denote significance at the 1,5 , and $10 \%$ levels, respectively. Driscoll-Kraay standard errors are in parentheses.

To further show the regulatory effect of this study, we present the following two figures. Figure 1 shows that under similar levels of TMT stability, the CSR performance of firms with greater slack resources is lower than that of firm with lesser slack resources. Meanwhile, Figure 2 shows that the slope of firms with a higher performance aspiration gap is smaller than that of firms with a lower performance aspiration gap, indicating that the performance aspiration gap negatively regulates the relationship between TMT stability and CSR performance. These two figures support Hypotheses 2 and 3. 


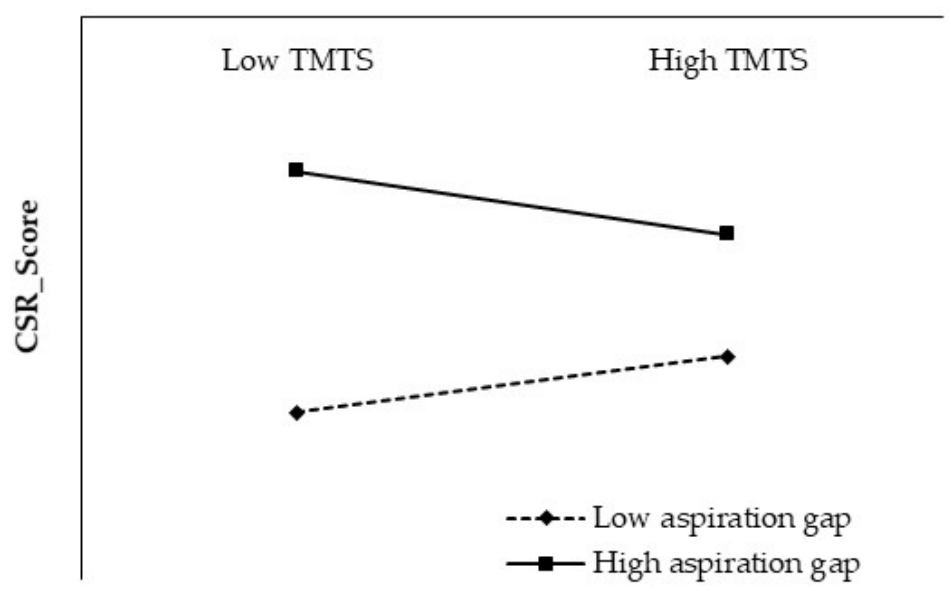

Figure 1. The moderating effect of performance aspiration gap on the relationship between TMT stability and CSR performance.

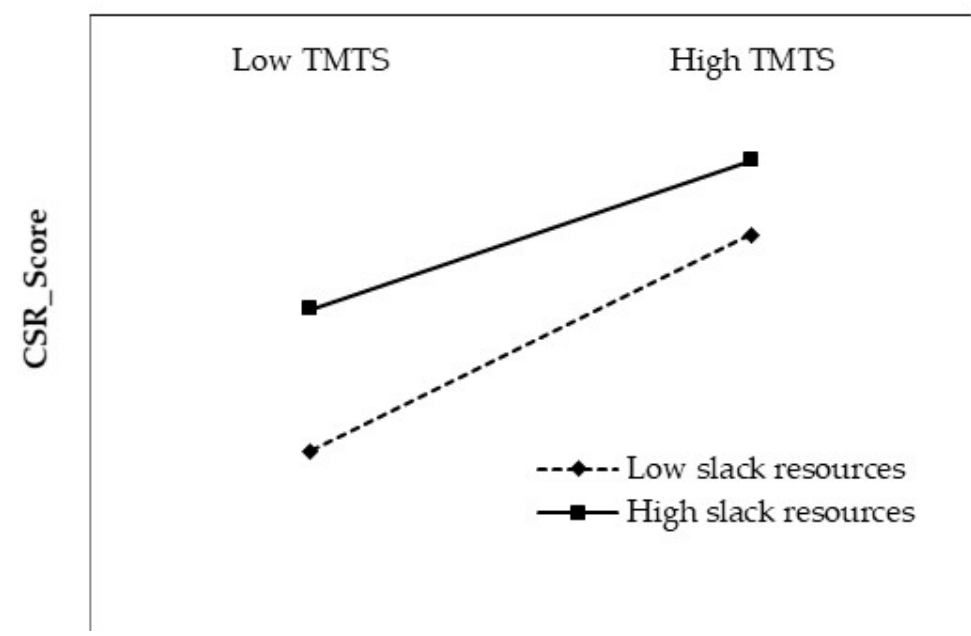

Figure 2. The moderating effect of slack resources on the relationship between TMT stability and CSR performance.

\subsection{Robustness Tests}

Heckman two-stage test: To address the possible problem of sample self-selection in the main assumptions, this study used the Heckman two-stage test. In the first stage, if the dummy variable TMTS_high was greater than the median TMT stability of the industry, it was set to 1, but it was 0 otherwise, and it was included in the TMT stability of the other firm in the same industry. The mean of TMTS_highmean was used as the instrumental variable, and the inverse Mills ratio (IMR) was calculated using the probit regression results at this stage. The IMR calculated in the first stage was added to the second stage for fitting. The results are shown in the Heckman second-phase panel in Table 5 (Models 1-4). The IMR was significantly negative and the result is consistent with the previous results, suggesting robustness of the results.

Propensity score matching: To alleviate potential endogeneity, we used the propensity score matching method. First, we set the dummy variable TMTS_high, then the propensity score matching (PSM) method was used to take the variables affecting TMT stability as the control variables. The nearest neighbour method was used for a 1:1 put back matching; logit regression was then performed, and finally, the matched data were used for regression. The results are shown in Table 5 PSM panel (Models 5-8), with a total of 12,490 firm/year samples. The final regression results are consistent with previous results, indicating robustness of the results. 
Table 5. Heckman second phase and PSM.

\begin{tabular}{|c|c|c|c|c|c|c|c|c|}
\hline \multirow{2}{*}{ Variables } & \multicolumn{4}{|c|}{ Heckman Second Phase } & \multicolumn{4}{|c|}{ PSM } \\
\hline & Model 1 & Model 2 & Model 3 & Model 4 & Model 5 & Model 6 & Model 7 & Model 8 \\
\hline TMTS & $\begin{array}{c}5.385^{* * * *} \\
(0.806)\end{array}$ & $\begin{array}{c}6.886^{* * *} \\
(0.815)\end{array}$ & $\begin{array}{l}9.485^{* * * *} \\
(1.465)\end{array}$ & $\begin{array}{c}10.389^{* * *} \\
(1.619)\end{array}$ & $\begin{array}{c}6.098^{* * *} \\
(1.379)\end{array}$ & $\begin{array}{c}7.740^{* * * *} \\
(1.585)\end{array}$ & $\begin{array}{c}9.557^{* * * *} \\
(2.026)\end{array}$ & $\begin{array}{c}10.618^{* * * *} \\
(2.170)\end{array}$ \\
\hline Aspiration gap & & $\begin{array}{c}14.153^{* *} \\
(4.872)\end{array}$ & & $\begin{array}{c}13.101 * * \\
(4.884)\end{array}$ & & $\begin{array}{c}15.290^{* *} \\
(6.369)\end{array}$ & & $\begin{array}{c}14.342^{* *} \\
(6.311)\end{array}$ \\
\hline $\begin{array}{c}\text { TMTS } \times \\
\text { Aspiration gap }\end{array}$ & & $\begin{array}{c}-12.032 * * * \\
(3.537)\end{array}$ & & $\begin{array}{c}-11.043^{* *} \\
(3.574)\end{array}$ & & $\begin{array}{c}-13.524 \text { ** } \\
(5.475)\end{array}$ & & $\begin{array}{c}-12.620 * * \\
(5.437)\end{array}$ \\
\hline Slack resources & & & $\begin{array}{c}3.136^{* * * *} \\
(0.472)\end{array}$ & $\begin{array}{c}2.780 * * * \\
(0.655)\end{array}$ & & & $\begin{array}{c}2.591 * * * \\
(0.530)\end{array}$ & $\begin{array}{c}2.257^{* * *} \\
(0.679)\end{array}$ \\
\hline $\begin{array}{c}\text { TMTS } \times \text { Slack } \\
\text { sources }\end{array}$ & & & $\begin{array}{c}-2.726^{* * * *} \\
(0.538)\end{array}$ & $\begin{array}{c}-2.408^{* * *} \\
(0.698)\end{array}$ & & & $\begin{array}{c}-2.200^{* * *} \\
(0.628)\end{array}$ & $\begin{array}{c}-1.901 * * \\
(0.758)\end{array}$ \\
\hline IMR & $\begin{array}{c}-54.633^{* * *} \\
(7.165)\end{array}$ & $\begin{array}{c}-61.936^{* * *} \\
(5.885)\end{array}$ & $\begin{array}{c}-54.718^{* * *} \\
(7.104)\end{array}$ & $\begin{array}{c}-61.750 * * * \\
(5.933)\end{array}$ & & & & \\
\hline Controls & YES & YES & YES & YES & YES & YES & YES & YES \\
\hline Constant & $\begin{array}{c}35.697^{* *} \\
(13.761)\end{array}$ & $\begin{array}{l}46.293^{* *} \\
(17.302)\end{array}$ & $\begin{array}{c}17.403 \\
(13.164)\end{array}$ & $\begin{array}{c}29.636 \\
(17.244)\end{array}$ & $\begin{array}{c}-71.464^{* * *} \\
(20.331)\end{array}$ & $\begin{array}{c}-76.489 * * * \\
(18.386)\end{array}$ & $\begin{array}{c}-88.822 * * * \\
(18.833)\end{array}$ & $\begin{array}{c}-91.642^{* * * *} \\
(17.884)\end{array}$ \\
\hline Year/Industry & YES & YES & YES & YES & YES & YES & YES & YES \\
\hline $\mathrm{N}$ & 23,084 & 23,084 & 23,084 & 23,084 & 12,490 & 12,490 & 12,490 & 12,490 \\
\hline Within $\mathrm{R}^{2}$ & 0.1789 & 0.1868 & 0.183 & 0.1901 & 0.1783 & 0.1855 & 0.1815 & 0.188 \\
\hline $\mathrm{F}$ & $795.7^{* * * *}$ & $113.3^{* * *}$ & $342.7^{* * *}$ & $136.6^{* * *}$ & $55.31 * * *$ & $158.6^{* * *}$ & $59.72 * * *$ & $148.0^{* * *}$ \\
\hline
\end{tabular}

Notes: ${ }^{* * *}$ and ${ }^{* *}$, denote significance at the $1 \%$, and $5 \%$ levels, respectively. Driscoll-Kraay standard errors are in parentheses.

Dependent variable sub-indictor test: Hexun.com divides corporate social responsibility into five sub-indictors: shareholder, society, employee, customer and consumer's right and interests, and environmental (see details in Lu et al., 2020. p. 15) [26]; it also publishes the scores of its sub-indictors. For further robust test, this study takes it as the dependent variables for regression and the results are in Table 6. Among them, the TMTS of the five sub-indictors are significantly positive. In terms of Shareholder (Model 1), it is similar to and consistent with the previous research. Among stakeholders, in terms of Society (Model 2), it may be that slack resources will not change the social donation and tax payment of enterprises, so it is not significant. Furthermore, the regulatory variable of slack resources remains significantly negative in terms of Environment (Model 3), Employee (Model 4), and Consumer (Model 5) responsibilities, but the performance aspiration gap is not significant, which may be related to the fact that managers will not change their attitudes towards CSR in the state of "loss" and "benefit".

Table 6. CSR sub-indictor group.

\begin{tabular}{cccccc}
\hline \multirow{2}{*}{ Variables } & Model 1 & Model 2 & Model 3 & Model 4 & Model 5 \\
\cline { 2 - 6 } & Shareholder & Society & Environment & Employee & Customer \\
\hline \multirow{2}{*}{ TMTS } & $4.178^{* * *}$ & $1.101^{* *}$ & $2.378^{* * *}$ & $1.186^{* * *}$ & $2.135^{* * *}$ \\
& $(0.408)$ & $(0.354)$ & $(0.597)$ & $(0.273)$ & $(0.324)$ \\
\hline \multirow{2}{*}{ Aspiration gap } & $11.455^{* *}$ & $3.823^{* *}$ & -0.574 & -0.109 & -0.274 \\
& $(3.641)$ & $(1.350)$ & $(0.571)$ & $(0.397)$ & $(0.497)$ \\
\hline TMTS $\times$ & $-9.620^{* * *}$ & $-3.317^{* *}$ & 0.322 & -0.095 & 0.050 \\
Aspiration gap & $(2.665)$ & $(1.056)$ & $(0.622)$ & $(0.394)$ & $(0.525)$ \\
\hline \multirow{2}{*}{ Slack resources } & $1.042^{* * *}$ & 0.096 & $0.812^{* * *}$ & $0.384 * * *$ & $0.623^{* * *}$ \\
& $(0.155)$ & $(0.126)$ & $(0.198)$ & $(0.101)$ & $(0.153)$ \\
\hline TMTS $\times$ Slack & $-0.387^{* *}$ & -0.018 & $-0.981^{* * *}$ & $-0.478^{* * *}$ & $-0.741^{* * *}$ \\
sources & $(0.164)$ & $(0.131)$ & $(0.222)$ & $(0.116)$ & $(0.171)$ \\
\hline
\end{tabular}


Table 6. Cont.

\begin{tabular}{cccccc}
\hline \multirow{2}{*}{ Variables } & Model 1 & Model 2 & Model 3 & Model 4 & Model 5 \\
\cline { 2 - 6 } & Shareholder & Society & Environment & Employee & Customer \\
\hline Controls & YES & YES & YES & YES & YES \\
\hline \multirow{2}{*}{ Constant } & $-21.800^{* * *}$ & $-14.837^{* * *}$ & $-18.617^{* * *}$ & $-16.828^{* * *}$ & $-18.073^{* * *}$ \\
& $(2.705)$ & $(1.997)$ & $(4.792)$ & $(2.500)$ & $(3.811)$ \\
\hline Year/Industry & YES & YES & YES & YES & YES \\
\hline Within $\mathrm{R}^{2}$ & 23,084 & 23,084 & 23,084 & 23,084 & 23,084 \\
\hline F & 0.1819 & 0.038 & 0.1523 & 0.1515 & 0.159 \\
\hline
\end{tabular}

Notes: $N=23,084 .{ }^{* * *}$ and ${ }^{* *}$, denote significance at the $1 \%$ and $5 \%$ levels, respectively. Driscoll-Kraay standard errors are in parentheses.

\section{Discussion}

Based on the upper echelon and agency theories, this study analyses the effects of TMT stability on CSR. The results show that the TMT faces agency problems under different situations. Empirical research shows that TMT stability is positively correlated with CSR performance, suggesting that firms with higher TMT stability tend to fulfil their social responsibility but also face less pressure in terms of financial performance, which makes them focus more on social responsibility performance and the interests of stakeholders. Firms with low TMT stability, because of frequent turnover and succession in TMT, may face financial breakthroughs but also show inadequate focus on social responsibility. Moreover, the results show that given similar levels of TMT stability, firms with CSR performance that have a small performance aspiration gap and poor slack resources are better off, which seems to contradict common sense. However, through detailed theoretical derivation, this study finds that the reason for this result lies in the existence of a certain principal-agent problem. Specifically, compared with firms in which the TMT has a higher performance aspiration gap (surplus), those in which the TMT has a lower performance aspiration gap (deficit) face greater pressure from shareholders and, thus, need to carry out their social responsibility to alleviate the pressure and achieve a positive image. In firms with abundant slack resources, the TMT is more inefficient, which aggravates the TMT members' self-interested behaviour to seek profits for themselves and can lead to a waste of resources and reduce the performance of social responsibility. Overall, this study concludes that TMT stability positively affects CSR performance and the performance aspiration gap and slack resources negatively mediate the relationship between TMT stability and CSR performance.

From a theoretical perspective, the positive linear relationship between TMT stability and CSR performance found in this study indicates that a stable TMT can help in maintaining the long-term development of a firm and promote the relationships among stakeholders [51]. Additionally, previous studies have shown that it takes years of investment for social responsibility to contribute to CFP and investments in social responsibility are unlikely to bring positive results in the short term $[15,93]$. Our study explored whether the current firm's management decision making and implementation have a certain degree of continuity despite personnel changes in the TMT, which affects the implementation of a long-term strategy for the firm. Previous studies have focused on the relationship between executives and social responsibility and the effects of TMT characteristics on social responsibility, and they rarely considered the impact of TMT stability on the long-term development of a firm. Our study fills this gap in the literature by showing that a firm can maintain a positive image by adequately fulfilling its social responsibility under a relatively stable TMT, thereby laying a solid foundation for the long-term development of the firm and providing support for subsequent financial performance. Further, relevant studies have shown that the TMT may be subject to moral failure when faced with great financial pressure $[22,94]$. This study supplements research on TMTs that change many managers, face significant financial performance pressure, and ignore CSR performance. Finally, this study also enriches the literature on upper echelon theory, which currently fo- 
cuses on the characteristics of senior managers (demographic characteristics, heterogeneity, etc.) $[16,30,95]$. Research is relatively lacking on TMT stability, which is an important TMT feature, especially with regard to long-term team cooperation that is consistent and unique, and on firms with more complex characteristics than those of single executives, and our study fills this gap in the literature.

This study has the following limitations: First, it is mainly based on data from Chinese listed firms, which are large in scale. However, the regulation of social responsibility in China is becoming increasingly strict. Most firms perform social responsibility mainly for compliance. In future research, the sample can be extended to include firms in other countries or smaller firms, and the conditions they face may be different from those encountered by the firms included in this study. This study shows that in a country with strong collectivism, such as China, an orderly change in TMT can easily help form a collective sense of honour that brings about a greater willingness to implement the firm's long-term oriented strategy. Follow-up research can expand other similar collectivist societies [96], such as Japan, Pakistan, and India, to explore whether the above relationship is established. Second, there is ambiguity regarding whether the TMT change is a result of changes in the attitude towards the performance of social responsibility arising from the changes in the characteristics of the TMT or whether it results from some other relationship formed by the TMT in the process of long-term cooperation to stimulate the performance of social responsibility. This point requires further investigation. Third, the core positions in the TMT, such as CEO and chairman, have a great impact on the business operation of the firm. Their change may have an impact on the established social responsibility strategy of the firm. However, such changes were not explored in this study due to certain limitations. Follow-up research can focus on exploring the impact of the change and succession of core position in the senior management team on CSR. Lastly, under the background of advocating rapid change in TMT members all over the world, of course, including China, how to build a TMT with strong management continuity and high team tacit understanding has become a difficult problem. Although this study explores the relationship between the TMT stability and CSR strategy, continuing to explore the topic of sustainable development strategy in this context can provide suggestions for the supervision of governance team.

\section{Conclusions}

Our study explores situational factors that affect the relationship between TMT stability and social responsibility. The main reason lies in the shaping of a collective sense of honour and attention to short-term performance. Specifically, the TMT has more information about its own ability and the firm's operations and may make self-serving decisions that might harm the interests of shareholders. Moreover, this study theoretically analysed in detail the psychological state of senior managers when faced with different performance aspiration gaps and their different attitudes towards CSR performance.

We found that when the TMT faces a performance aspiration surplus, it reduces the performance of social responsibility and may seek self-interest from slack resources. Furthermore, TMT members become "complacent" and unwilling to perform other activities as they have already completed their main tasks. However, when faced with performance aspiration deficit, they may fear dismissal because of inadequate performance and, thus, focus on pleasing the stakeholders and become willing to undertake social responsibility. When there are slack resources, TMT members become self-interested and reduce CSR performance. Lastly, our study enriches the current literature on the principal-agent problem involving senior executives under different situations and it can serve as reference for management practice.

From a management perspective, our study shows that having a stable TMT can help in the fulfilment of social responsibility to meet a firm's long-term development goal and improve its financial performance. Therefore, a firm should keep a good succession plan, plan the changes in senior executives in advance, and avoid changing many managers at one time. A stable TMT promotes good relationship with stakeholders, helping the firm 
to achieve long-term sustainable development and high performance in the future. The rapid replacement of executives can bring new technologies and new ideas to enterprises and make enterprises adapt to the changing external environment. However, if the knowledge is introduced blindly, this change in managers will inevitably break the long-term strategic planning of the enterprise, will affect the team cooperation atmosphere, and is not conducive to the formation of collective sense of honour. Cultivate senior executives in an orderly manner and introduce an appropriate number of managers in a planned way, so as to retain the corporate culture and focus on the long-term business strategy of the firm so as to keep the firm in a leading position in the changing environment.

This study also provides relevant suggestions for governance. Specifically, the governance team needs to pay more attention to CSR performance, together with the achievement of good financial performance, and conduct investigations as necessary to prevent selfinterested TMT members from causing harm to the firm's long-term reputation, assets, and funds for future sustainable development. The governance team should also be cautious about the renewal requirements of managers. Although the renewal of managers can improve the TMT stability, it is unfavourable to the selection of talents and firm innovation. In particular, it may lead to excessive power of some managers, may aggravate imperial behaviour, and is not conducive to organisation operation. Meanwhile, supervising the control of slack resources, maximising the use of assets, and improving the firm's total factor productivity should be encouraged to reduce the waste of slack resources and minimise principal-agent problems. In Chinese firms, good TMT succession and the selection of excellent talents can play an important role in enhancing firm performance. At the same time, a good sense of collective honour can make them pay more attention to long-term benefits. This study examines the importance of TMT stability from the strategic perspective of social responsibility, which requires long-term investment. The large-scale reorganisation of the TMT will reduce the strategic continuity of the firm and interfere with the plans that need long-term investment, and the firm will be more inclined to pursue short-term profits.

Author Contributions: Conceptualization, Q.Z.; methodology and software, Q.Z.; validation, D.L.; writing_original draft preparation, Q.Z.; writing—review and editing, D.L.; funding acquisition, D.L. All authors have read and agreed to the published version of the manuscript.

Funding: This research was funded by the National Natural Science Foundation of China, grant number 71273160 .

Institutional Review Board Statement: Not applicable.

Informed Consent Statement: Not applicable.

Data Availability Statement: Not applicable.

Conflicts of Interest: The authors declare no conflict of interest.

\section{References}

1. Brickson, S.L. Organizational identity orientation: The genesis of the role of the firm and distinct forms of social value. Acad. Manag. Rev. 2007, 32, 864-888. [CrossRef]

2. Calvo, N.; Calvo, F. Corporate social responsibility and multiple agency theory: A case study of internal stakeholder engagement. Corp. Soc. Responsib. Environ. Manag. 2018, 25, 1223-1230. [CrossRef]

3. Murray, K.B.; Montanari, J.B. Strategic management of the socially responsible firm: Integrating management and marketing theory. Acad. Manag. Rev. 1986, 11, 815-827. [CrossRef]

4. Lichtenthaler, U. Absorptive capacity, environmental turbulence, and the complementarity of organizational learning processes. Acad. Manag. J. 2009, 52, 822-846. [CrossRef]

5. Kaplan, S.N.; Klebanov, M.M.; Sorensen, M. Which CEO characteristics and abilities matter? J. Financ. 2012, 67, 973-1007. [CrossRef]

6. Eberle, D.; Berens, G.; Li, T. The impact of interactive corporate social responsibility communication on corporate reputation. J. Bus. Ethics 2013, 118, 731-746. [CrossRef]

7. Liu, X. Impression management against early dismissal? CEO succession and corporate social responsibility. Corp. Soc. Responsib. Environ. Manag. 2020, 27, 999-1016. [CrossRef] 
8. Tang, Y.; Qian, C.; Chen, G.; Shen, R. How CEO hubris affects corporate social (ir) responsibility. Strateg. Manag. J. 2015, 36, 1338-1357. [CrossRef]

9. Uyar, A.; Kuzey, C.; Kilic, M.; Karaman, A.S. Board structure, financial performance, corporate social responsibility performance, CSR committee, and CEO duality: Disentangling the connection in healthcare. Corp. Soc. Responsib. Environ. Manag. 2021. [CrossRef]

10. Bear, S.; Rahman, N.; Post, C. The impact of board diversity and gender composition on corporate social responsibility and firm reputation. J. Bus. Ethics 2010, 97, 207-221. [CrossRef]

11. Zhang, J.Q.; Zhu, H.; Ding, H.-B. Board composition and corporate social responsibility: An empirical investigation in the post Sarbanes-Oxley era. J. Bus. Ethics 2013, 114, 381-392. [CrossRef]

12. Rao, K.; Tilt, C. Board composition and corporate social responsibility: The role of diversity, gender, strategy and decision making. J. Bus. Ethics 2016, 138, 327-347. [CrossRef]

13. Krishnamurti, C.; Velayutham, E. The influence of board committee structures on voluntary disclosure of greenhouse gas emissions: Australian evidence. Pac.-Basin Financ. J. 2018, 50, 65-81. [CrossRef]

14. Dooley, R.S.; Fryxell, G.E. Are conglomerates less environmentally responsible? An empirical examination of diversification strategy and subsidiary pollution in the US chemical industry. J. Bus. Ethics 1999, 21, 1-14. [CrossRef]

15. Barnett, M.L.; Salomon, R.M. Does it pay to be really good? Addressing the shape of the relationship between social and financial performance. Strateg. Manag. J. 2012, 33, 1304-1320. [CrossRef]

16. Thomas, A.S.; Simerly, R.L. The chief executive officer and corporate social performance: An interdisciplinary examination. J. Bus. Ethics 1994, 13, 959-968. [CrossRef]

17. Burke, L.; Logsdon, J.M. How corporate social responsibility pays off. Long Range Plan. 1996, 29, 495-502. [CrossRef]

18. Jensen, M.C.; Meckling, W.H. Theory of the firm: Managerial behavior, agency costs and ownership structure. J. Financ. Econ. 1976, 3, 305-360. [CrossRef]

19. Freeman, R.E. Strategic Management: A stakeholder Approach; Cambridge University Press: Cambridge, UK, 2010.

20. Holmström, B. Managerial incentive problems: A dynamic perspective. Rev. Econ. Stud. 1999, 66, 169-182. [CrossRef]

21. Murphy, K.J.; Zimmerman, J.L. Financial performance surrounding CEO turnover. J. Account. Econ. 1993, 16, 273-315. [CrossRef]

22. Mishina, Y.; Dykes, B.J.; Block, E.S.; Pollock, T.G. Why "good" firms do bad things: The effects of high aspirations, high expectations, and prominence on the incidence of corporate illegality. Acad. Manag. J. 2010, 53, 701-722. [CrossRef]

23. Albuquerque, R.; Koskinen, Y.; Zhang, C. Corporate social responsibility and firm risk: Theory and empirical evidence. Manag. Sci. 2019, 65, 4451-4469. [CrossRef]

24. Minor, D.; Morgan, J. CSR as reputation insurance: Primum non nocere. Calif. Manag. Rev. 2011, 53, 40-59. [CrossRef]

25. Su, K. Does religion benefit corporate social responsibility (CSR)? Evidence from China. Corp. Soc. Responsib. Environ. Manag. 2019, 26, 1206-1221. [CrossRef]

26. Lu, Q.; Chen, S.; Chen, P. The Relationship between Female Top Managers and Corporate Social Responsibility in China: The Moderating Role of the Marketization Level. Sustainability 2020, 12, 7730. [CrossRef]

27. Yang, B. Confucianism, socialism, and capitalism: A comparison of cultural ideologies and implied managerial philosophies and practices in the PR China. Hum. Resour. Manag. Rev. 2012, 22, 165-178. [CrossRef]

28. Shenkar, O.; Ronen, S. Structure and importance of work goals among managers in the People's Republic of China. Acad. Manag. J. 1987, 30, 564-576. [CrossRef]

29. Hambrick, D.C.; Mason, P.A. Upper echelons: The organization as a reflection of its top managers. Acad. Manag. Rev. 1984, 9, 193-206. [CrossRef]

30. Manner, M.H. The impact of CEO characteristics on corporate social performance. J. Bus. Ethics 2010, 93, 53-72. [CrossRef]

31. Chin, M.K.; Hambrick, D.C.; Treviño, L.K. Political ideologies of CEOs: The influence of executives' values on corporate social responsibility. Adm. Sci. Q. 2013, 58,197-232. [CrossRef]

32. Davidson, R.H.; Dey, A.; Smith, A.J. CEO materialism and corporate social responsibility. Account. Rev. 2019, 94, 101-126. [CrossRef]

33. McCarthy, S.; Oliver, B.; Song, S. Corporate social responsibility and CEO confidence. J. Bank Financ. 2017, 75, 280-291. [CrossRef]

34. Fabrizi, M.; Mallin, C.; Michelon, G. The role of CEO's personal incentives in driving corporate social responsibility. J. Bus. Ethics 2014, 124, 311-326. [CrossRef]

35. Daboub, A.J.; Rasheed, A.M.; Priem, R.L.; Gray, D. Top management team characteristics and corporate illegal activity. Acad. Manag. Rev. 1995, 20, 138-170. [CrossRef]

36. $\mathrm{Hu}, \mathrm{Y}$;; Zhang, Q.; Wang, X. Potentials of top management team career development and corporate social responsibility: A study on listed manufacturing companies in China. Career Dev. Int. 2019, 24, 560-579. [CrossRef]

37. Huang, X.; Nakagawa, K.; Li, J. Impacts of top management team characteristics on corporate charitable activity: Evidence from Chinese Listed Companies. J. Int. Bus. Econ. 2019, 7, 60-73. [CrossRef]

38. Shahab, Y.; Ntim, C.G.; Chengang, Y.; Ullah, F.; Fosu, S. Environmental policy, environmental performance, and financial distress in China: Do top management team characteristics matter? Bus. Strateg. Environ. 2018, 27, 1635-1652. [CrossRef]

39. Carr, A.S.; Pearson, J.N. Strategically managed buyer-supplier relationships and performance outcomes. J. Oper. Manag. 1999, 17, 497-519. [CrossRef] 
40. Liao, Z. Is environmental innovation conducive to corporate financing? The moderating role of advertising expenditures. Bus. Strateg. Environ. 2020, 29, 954-961. [CrossRef]

41. Ali Shah, S.Z.; Akbar, S. Value relevance of advertising expenditure: A review of the literature. Int. J. Manag. Rev. 2008, 10, 301-325. [CrossRef]

42. Schlesinger, L.A.; Kiefer, C.F. Just Start: Take Action, Embrace Uncertainty, Create the Future; Harvard Business Review Press: Boston, MA, USA, 2012.

43. Guiso, L.; Sapienza, P.; Zingales, L. The value of corporate culture. J. Financ. Econ. 2015, 117, 60-76. [CrossRef]

44. Cui, A.S.; Calantone, R.J.; Griffith, D.A. Strategic change and termination of interfirm partnerships. Strateg. Manag. J. 2011, 32, 402-423. [CrossRef]

45. Li, W.; Bruton, G.D.; Li, X.; Wang, S. Transgenerational Succession and R\&D Investment: A Myopic Loss Aversion Perspective. Entrep. Theory Pract. 2021, 46, 193-222. [CrossRef]

46. Kang, C.; Germann, F.; Grewal, R. Washing away your sins? Corporate social responsibility, corporate social irresponsibility, and firm performance. J. Mark. 2016, 80, 59-79. [CrossRef]

47. Brammer, S.; Millington, A. Corporate reputation and philanthropy: An empirical analysis. J. Bus. Ethics 2005, 61, 29-44. [CrossRef]

48. Godfrey, P.C. The relationship between corporate philanthropy and shareholder wealth: A risk management perspective. Acad. Manag. Rev. 2005, 30, 777-798. [CrossRef]

49. Husted, B.W.; Allen, D.B. Corporate Social Strategy: Stakeholder Engagement and Competitive Advantage; Cambridge University Press: Cambridge, UK, 2010.

50. Korsgaard, M.A.; Schweiger, D.M.; Sapienza, H.J. Building commitment, attachment, and trust in strategic decision-making teams: The role of procedural justice. Acad. Manag. J. 1995, 38, 60-84. [CrossRef]

51. Amason, A.C. Distinguishing the effects of functional and dysfunctional conflict on strategic decision making: Resolving a paradox for top management teams. Acad. Manag. J. 1996, 39, 123-148. [CrossRef]

52. Uskul, A.K.; Oyserman, D.; Schwarz, N. Cultural Emphasis on Honor, Modesty, or Self-Enhancement: Implications for the Survey Response Process; Kent Academic Repository: Kent, UK, 2010.

53. Tajfel, H.; Fraser, C.; Jaspars, J.M.F. The Social Dimension: Volume 1: European Developments in Social Psychology; Cambridge University Press: Cambridge, UK, 1984; Volume 1.

54. Dangelico, R.M.; Pontrandolfo, P.; Pujari, D. Developing sustainable new products in the textile and upholstered furniture industries: Role of external integrative capabilities. J. Prod. Innov. Manag. 2013, 30, 642-658. [CrossRef]

55. Reitenga, A.L.; Tearney, M.G. Mandatory CEO retirements, discretionary accruals, and corporate governance mechanisms. J. Account. Audit. Financ. 2003, 18, 255-280. [CrossRef]

56. Oh, W.-Y.; Chang, Y.K.; Cheng, Z. When CEO career horizon problems matter for corporate social responsibility: The moderating roles of industry-level discretion and blockholder ownership. J. Bus. Ethics 2016, 133, 279-291. [CrossRef]

57. López, M.V.; Garcia, A.; Rodriguez, L. Sustainable development and corporate performance: A study based on the Dow Jones sustainability index. J. Bus. Ethics 2007, 75, 285-300. [CrossRef]

58. McWilliams, A.; Siegel, D. Corporate social responsibility: A theory of the firm perspective. Acad. Manag. Rev. 2001, 26, 117-127. [CrossRef]

59. Westphal, J.D.; Fredrickson, J.W. Who directs strategic change? Director experience, the selection of new CEOs, and change in corporate strategy. Strateg. Manag. J. 2001, 22, 1113-1137. [CrossRef]

60. Davis, J.H.; Schoorman, F.D.; Donaldson, L. Toward a stewardship theory of management. Acad. Manag. Rev. 1997, 22, 20-47. [CrossRef]

61. Carroll, A.B. The pyramid of corporate social responsibility: Toward the moral management of organizational stakeholders. Bus. Horiz. 1991, 34, 39-48. [CrossRef]

62. Man, D.C.; Lam, S.S. The effects of job complexity and autonomy on cohesiveness in collectivistic and individualistic work groups: A cross-cultural analysis. J. Organ. Behav. 2003, 24, 979-1001. [CrossRef]

63. Cyert, R.M.; March, J.G. A Behavioral Theory of the Firm; Englewood Cliffs: Bergen, NJ, USA, 1963; Volume 2.

64. Kim, J.-Y.; Kim, J.-Y.; Miner, A.S. Organizational learning from extreme performance experience: The impact of success and recovery experience. Organ. Sci. 2009, 20, 958-978. [CrossRef]

65. Oliver, C. The antecedents of deinstitutionalization. Organ. Stud. 1992, 13, 563-588. [CrossRef]

66. Coughlan, A.T.; Schmidt, R.M. Executive compensation, management turnover, and firm performance: An empirical investigation. J. Account. Econ. 1985, 7, 43-66. [CrossRef]

67. Bradley, S.W.; Shepherd, D.A.; Wiklund, J. The importance of slack for new organizations facing 'tough'environments. J. Manag. Stud. 2011, 48, 1071-1097. [CrossRef]

68. Salancik, G.R.; Pfeffer, J. A social information processing approach to job attitudes and task design. Adm. Sci. Q. 1978, 23, 224-253. [CrossRef] [PubMed]

69. Sassen, R.; Hinze, A.-K.; Hardeck, I. Impact of ESG factors on firm risk in Europe. J. Bus. Econ. 2016, 86, 867-904. [CrossRef]

70. Bourgeois, L.J., III. On the measurement of organizational slack. Acad. Manag. Rev. 1981, 6, 29-39. [CrossRef]

71. Leibenstein, H. Organizational or frictional equilibria, X-efficiency, and the rate of innovation. Q. J. Econ. 1969, 83, 600-623. [CrossRef] 
72. Gruber, M. Exploring the origins of organizational paths: Empirical evidence from newly founded firms. J. Manag. 2010, 36, 1143-1167. [CrossRef]

73. Ju, M.; Zhao, H.X. Behind organizational slack and firm performance in China: The moderating roles of ownership and competitive intensity. Asia Pac. J. Manag. 2009, 26, 701-717. [CrossRef]

74. Masulis, R.W.; Wang, C.; Xie, F. Corporate governance and acquirer returns. J. Financ. 2007, 62, 1851-1889. [CrossRef]

75. Cheng, J.L.; Kesner, I.F. Organizational slack and response to environmental shifts: The impact of resource allocation patterns. J. Manag. 1997, 23, 1-18. [CrossRef]

76. Xu, E.M.; Yang, H.; Quan, J.M.; Lu, Y. Organizational slack and corporate social performance: Empirical evidence from China's public firms. Asia Pac. J. Manag. 2015, 32, 181-198. [CrossRef]

77. Zhong, M.; Xu, R.; Liao, X.; Zhang, S. Do CSR ratings converge in China? A comparison between RKS and Hexun scores. Sustainability 2019, 11, 3921. [CrossRef]

78. Crutchley, C.E.; Garner, J.L.; Marshall, B.B. An examination of board stability and the long-term performance of initial public offerings. Finan. Manag. 2002, 63-90. [CrossRef]

79. Ref, O.; Shapira, Z. Entering new markets: The effect of performance feedback near aspiration and well below and above it. Strateg. Manag. J. 2017, 38, 1416-1434. [CrossRef]

80. Bromiley, P.; Harris, J.D. A comparison of alternative measures of organizational aspirations. Strateg. Manag. J. 2014, 35, 338-357. [CrossRef]

81. Xie, E.; Huang, Y.; Peng, M.W.; Zhuang, G. Resources, aspirations, and emerging multinationals. J. Leadersh. Organ. Stud. 2016, 23, 144-161. [CrossRef]

82. Chen, W.-R. Determinants of firms' backward-and forward-looking R\&D search behavior. Organ. Sci. 2008, 19, 609-622. [CrossRef]

83. Shahab, Y.; Ntim, C.G.; Ullah, F. The brighter side of being socially responsible: CSR ratings and financial distress among Chinese state and non-state owned firms. Appl. Econ. Lett. 2019, 26, 180-186. [CrossRef]

84. Roberts, R.W. Determinants of corporate social responsibility disclosure: An application of stakeholder theory. Account. Organ. Soc. 1992, 17, 595-612. [CrossRef]

85. Hong, H.; Kacperczyk, M. The price of sin: The effects of social norms on markets. J. Financ. Econ. 2009, 93, 15-36. [CrossRef]

86. Cai, Y.; Jo, H.; Pan, C. Doing well while doing bad? CSR in controversial industry sectors. J. Bus. Ethics 2012, 108, 467-480. [CrossRef]

87. Li, W.; Zhang, R. Corporate social responsibility, ownership structure, and political interference: Evidence from China. J. Bus. Ethics 2010, 96, 631-645. [CrossRef]

88. Khan, T.M.; Gang, B.; Fareed, Z.; Khan, A. How does CEO tenure affect corporate social and environmental disclosures in China? Moderating role of information intermediaries and independent board. Environ. Sci. Pollut. Res. 2021, 28, 9204-9220. [CrossRef] [PubMed]

89. Liao, L.; Lin, T.P.; Zhang, Y. Corporate board and corporate social responsibility assurance: Evidence from China. J. Bus. Ethics 2018, 150, 211-225. [CrossRef]

90. Oh, W.-Y.; Chang, Y.K.; Kim, T.-Y. Complementary or substitutive effects? Corporate governance mechanisms and corporate social responsibility. J. Manag. 2018, 44, 2716-2739. [CrossRef]

91. Driscoll, J.C.; Kraay, A.C. Consistent covariance matrix estimation with spatially dependent panel data. Rev. Econ. Statist. 1998, 80, 549-560. [CrossRef]

92. Guo, M.; He, L.; Zhong, L. Business groups and corporate social responsibility: Evidence from China. Emerg. Mark. Rev. 2018, 37, 83-97. [CrossRef]

93. Barnett, M.L.; Salomon, R.M. Beyond dichotomy: The curvilinear relationship between social responsibility and financial performance. Strateg. Manag. J. 2006, 27, 1101-1122. [CrossRef]

94. Deng, X.; Long, X.; Schuler, D.A.; Luo, H.; Zhao, X. External corporate social responsibility and labor productivity: A S-curve relationship and the moderating role of internal CSR and government subsidy. Corp. Soc. Responsib. Environ. Manag. 2020, 27, 393-408. [CrossRef]

95. Liu, Y.; Gulzar, M.A.; Zhang, Z.; Yang, Q. Do interaction and education moderate top management team age heterogeneity and corporate social responsibility? Soc. Behav. Pers. 2018, 46, 2063-2079. [CrossRef]

96. House, R.J.; Hanges, P.J.; Javidan, M.; Dorfman, P.W.; Gupta, V. Culture, Leadership, and Organizations: The GLOBE Study of 62 Societies; Sage publications: London, UK, 2004. 